\title{
Endokrin Bozucu Kimyasallar ve Tekstil Alanında Kullanımları
}

\author{
Endocrine Disrupting Chemicals and Their Use in Textile Industry
}

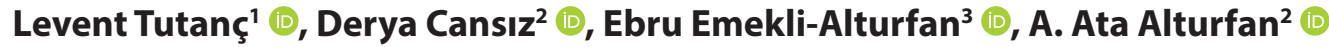 \\ IIsstanbul Üniversitesi-Cerrahpaşa, Adli Bilimler Enstitüsü, Fen Bilimleri Bölümü, İstanbul, Türkiye \\ ${ }^{2}$ Istanbul Üniversitesi-Cerrahpaşa, Cerrahpaşa Tıp Fakültesi, Tıbbi Biyokimya Anabilim Dalı, İstanbul, Türkiye \\ ${ }^{3}$ Marmara Üniversitesi Diş Hekimliği Fakültesi, Biyokimya Bölümü, İstanbul, Türkiye
}

ORCID ID: L.T. 0000-0001-8641-4252; D.C. 0000-0002-6274-801X; E.E.A. 0000-0003-0528-9002; A.A.A. 0000-0003-2419-8587

Cite this article as: Tutanc L, Cansız D, Emekli-Alturfan E, Alturfan A. Endokrin bozucu kimyasallar ve tekstil alanında kullanımları. Experimed 2021; 11(2): 130-9.

\section{öz}

Son yıllarda endokrin bozucu kimyasallar (EBK) olarak adlandırılan ve insan yapımı olan bileşikler bilim dünyasında dikkatleri üzerine çekmektedir. Bu kimyasallar endokrin sistemin gelişimini ve fonksiyonunu değiştirebilmekte, hormonların bağlanma, taşınma, üretim ve vücuttan uzaklaştırılmaları üzerine etki etmektedir. Şu ana kadar yapılan bilimsel çalışmaların çoğu EBK'ların kanserojen etkilerine, balıkların ve memelilerin üreme sistemlerine olan etkilerine odaklanmıştır. Amerika Birleşik Devletleri Çevre Koruma Ajansı'na (EPA) göre hormon taklit edebilme özelliği olan EBK'lar, homeostazın devamından ve gelişim ile ilgili süreçlerin regülasyonundan sorumlu olan hormonların üretimine, salgılanmasına, taşınmasına, bağlanmasına, metabolizmasına ya da eliminasyonuna müdahale edebilen dışsal ajanlar olarak tanımlanmaktadır. Dolayısıyla bu eksojen kimyasallardan en fazla endokrin sistem etkilenmektedir. Endokrin bozucular, hücrenin yağ dokusunda depolanabilirler. Bu sebeple EBK'ların çevre ve toplum sağlığı üzerindeki etkilerini minimuma indirmek adına sıkı önlemlerin alınması gerekmektedir. Insanlar ve hayvanlar EBK'lara günlük hayatta pek çok yol ile maruz kalabilmektedir. İnsanların maruz kaldığı yollardan biri de tekstil ürünlerinde bulunan EBK'lardır.

EBK'ların sağlık üzerindeki olumsuz etkileri literatürdeki birçok araştırmada gözler önüne serilmiştir. Bilim ve teknolojinin bu kadar hızlı ilerlediği bir çağda bugüne kadar varlığı tespit edilen ve henüz tespit edilmemiş olan bu kimyasallarla kontamine olmamak imkansız gibi görünmektedir.

Bu derlemede en yaygın EBK'lardan bisfenol A ve fitalatların etkileri hakkında bilgi verildikten sonra tekstil ürünlerinde belirlenen bisfenol A ve fitalatlardan bahsedilecektir.

Anahtar Kelimeler: Endokrin bozucu kimyasallar, bisfenol A, fitalat, tekstil sanayi

\begin{abstract}
In recent years, man-made compounds referred to as endocrine disrupting chemicals (EDC) have attracted the attention of the scientific world. These chemicals can change the development and function of the endocrine system, and affect the binding, transport, production, and removal of hormones from the body. Most of the studies conducted so far have focused on the carcinogenic effects of EDCs and their effects on the reproductive system of fish and mammals. According to the US Environmental Protection Agency (EPA), EDCs with the ability to mimic hormones are defined as exogenous agents that can interfere with the production, secretion, transport, binding, metabolism, or elimination of hormones in the body responsible for the maintenance of homeostasis and regulation of developmental processes. Therefore, the endocrine system is mostly affected by these exogenous chemicals. Endocrine disruptors can be stored in adipose tissues. For this reason, it is essential to make strict rules to minimize the effects of EDCs on the environment and public health. Humans and animals can be exposed to EDCs in many ways in daily life.
\end{abstract}

The negative effects of EDCs on health have been revealed in many studies in literature. In a global world where science and technology are advancing so rapidly, it seems nearly impossible not to be contaminated with these chemicals.

In this review, after giving information about the effects of bisphenol $\mathrm{A}$ and phthalates, the most common EDCs bisphenol A and phthalates used in textile products will be mentioned.

Keywords: Endocrine disrupting chemicals, bisphenol A, phthalates, textile industry 


\section{Endokrin Bozucu Kimyasallar ve Sınıflandırılmaları}

Endokrin bozucular hem doğal olarak bazı canlılar tarafından sentez edilebilirken hem de endüstriyel faaliyetler neticesinde sentetik olarak üretilebilirler. Doğal endokrin bozucuların sentetik olanlara göre yarı ömürleri çok daha kısa olmakta, kolaylıkla yıkılabilmekte, vücuttan hızlı bir şekilde atılabilmekte ve dokularda daha düşük konsantrasyonda birikebilmektedirler. Bu nedenle doğal endokrin bozucuların ciddi yan etkileri gözlenmemiştir (5). Bu kategoriye giren endokrin bozucular fitoöstrojenler olarak tanımlanır. Fitoöstrojenler doğal hormon yapısında olup, depolanma özellikleri yoktur. Doğal endokrin bozuculara örnek olarak kumestrol ve genistein verilebilir. Her iki fitoöstrojen özellikle üzüm, soğan, brokoli, kırmızı şarap, domates, elma ve soya fasülyesi gibi besinlerde bol miktarda bulunur $(6,7)$.

Sentetik endokrin bozuculara ise örnek olarak fitalatlar, bisfenol A (BFA), poliklorlu bifeniller (PCB), dioksinler, vinklozolin, dietilstilbestrol, diklorodifeniltrikloroetan (DDT) gibi moleküller verilebilir. Bu sentetik kimyasallar, tarım ilaçları, temizlik ürünleri, boya, plastik ve çözücüler gibi endüstriyel kimyasalların içinde bulunmakla birlikte, yağda çözünebilme özelliklerinden dolayı canlılarda yağ dokusunda depolanabilmekte ve doğal endokrin bozuculara göre vücutta daha uzun süreli kalabilmektedirler. Bu nedenle organizmaya zarar verme potansiyelleri doğal endokrin bozuculara göre daha fazladır. Eğer sentetik kimyasallara maruziyet fetal dönemde gerçekleşirse, ciddi sağlık sorunlarıyla karşı karşıya kalınabilmektedir $(7,8)$.

\section{Endokrin Bozucu Kimyasalların Etki Mekanizmaları}

Endokrin bozucular etkilerini farklı mekanizmalar üzerinden gösterir. Pek çok endokrin bozucu kimyasal (EBK) steroid, amino asit ve peptit/protein yapıdaki hormonların reseptör dönüşümünü (turnover) modifiye ederek, endojen hormon konsantrasyonunu etkileyerek veya sinyal mekanizmalarını bozarak işlev görür (9). Bazı endokrin bozucular ise etkilerini direkt olarak genler üzerinden gerçekleştirir. Bunun yanı sıra östrojen türevleri DNA hasarı yapabilmekte, çeşitli hücre tiplerinde malign farkIılaşmaya sebep olabilmektedir (10). Endokrin bozucular gen ekspresyonunda kalıcı etkilere de yol açabilir. Buna göre, fitalatlar tarafından hayatın erken dönemlerinde genlerde meydana gelen metilasyon reaksiyonlarının hayatın ileri dönemlerinde canlı sağlığını olumsuz yönde etkileyeceği ve bu olumsuzlukların genetik geçişli olabileceği düşünülmektedir (10).

Çoğu endokrin bozucu, üreme ile ilgili olan yan etkilerini östrojen ve androjen reseptörlerine bağlanarak gerçekleştirir. Bu etkiyi post-transkripsiyonel ya da transkripsiyonel mekanizmaları stimüle ya da inhibe etme yolu ile yapar. Membran üzerinde lokalize olan nükleer olmayan steroid hormon reseptörleri (membran üzerindeki östrojen reseptörleri), nükleer hormon reseptörleri (tiroid, östrojen reseptörleri, androjen reseptörleri, retinoid reseptörler, progesteron reseptörleri) ve nonsteroid reseptörler (serotonin, dopamin, norepinefrin reseptörleri) ligandlarını bağladıktan sonra iyon kanalları, ikinci mesajcılar ve sinyal iletim mekanizmaları üzerinden etkilerini gösterir $(7,10)$. Örneğin hem BFA'nın hem de fitalatların epitel-mezenkimal tranzisyona neden olduğu belirlenmiştir. Bununla birlikte bu kimyasallar genlerin ifadesini artırarak ve/veya azaltarak sinyal iletiminin regülasyonunda da rol oynamaktadırlar (11,12). Endokrin bozucular bu mekanizmalar üzerinden beyin, hipofiz, uterus, meme bezi ve prostat bezi hücrelerinde etkilerini gösterirler (10).

EBK'lar ayrıca hormonları taklit edebilirler, steroid hormonlar ve peptit yapıdaki hormonların etkilerini azaltabilir, olması gerekenden daha yüksek konsantrasyonda peptit/protein ya da steroid hormon sentezine neden olabilirler. Ayrıca hormonların taşınmasına ve yıkım mekanizması üzerine etki edebilir ve hormon-reseptör etkileşimi sonrası sinyal iletimini bozabilirler. Bu etkilerin biri veya birkaç tanesi bir arada da gerçekleşebilirler (13-15). EBK'ların etki mekanizmaları Şekil 1'de özetlenmiştir.

Endokrin bozucular enzimatik yolaklar üzerine de etki edebilirler. Bu kimyasallar, steroid biyosentezindeki enzimatik yolakla-

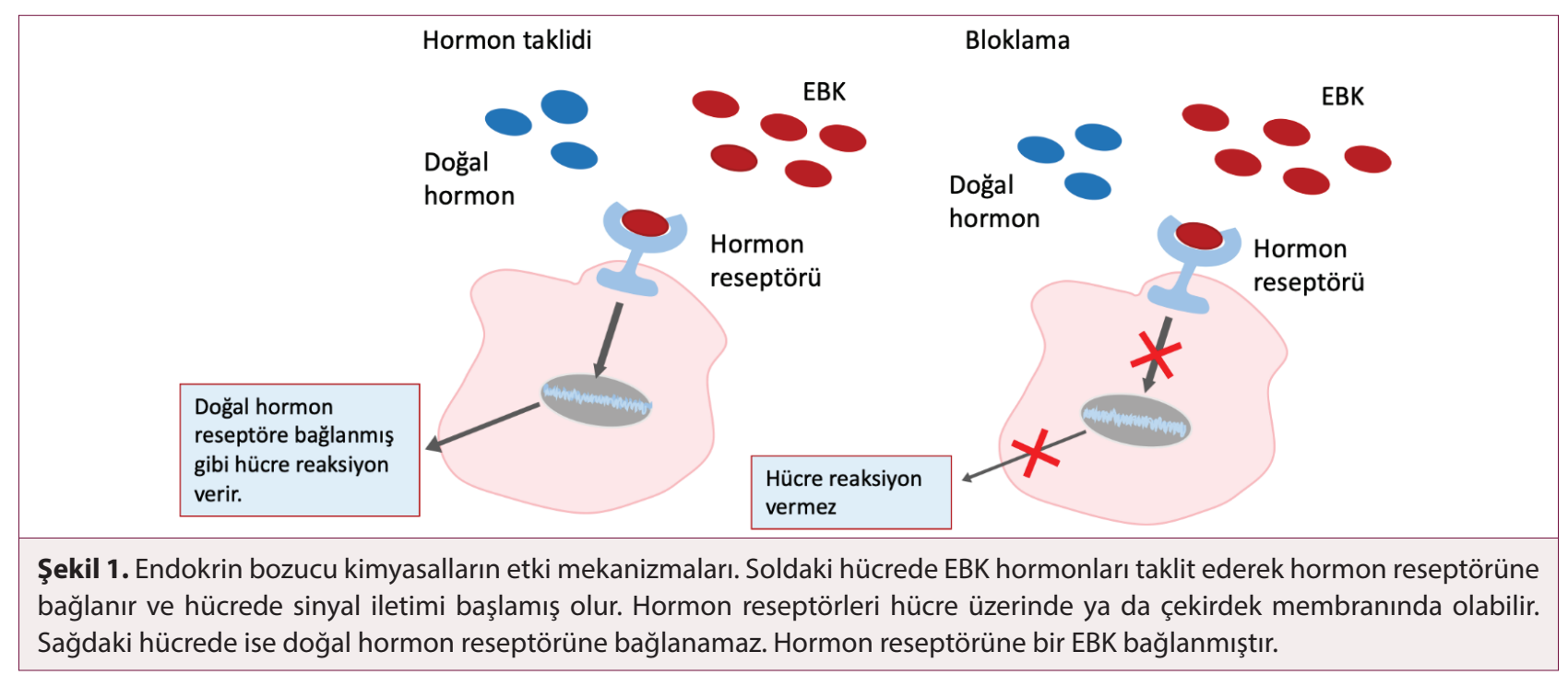


rı, cinsel davranışları ve endokrin sistemi harekete geçiren bazı mekanizmaları bozabilir, steroidogenezdeki enzimlerin ve östrojenlerin metabolik faaliyetlerini inhibe edilebilirler. Örneğin, bazı PCB metabolitleri sülfotransferazları inhibe ederek dolaşımdaki östradiol seviyesinin artışına neden olabilirler (16-18).

Endokrin bozucuların vücudun farklı bölümleri üzerindeki etkileri karmaşık olmakla birlikte bu etkiler canlıların yaşadıkları bölgeye, mevsime, beslenme alışkanlıklarına, yaş ve genetik farklılıklara bağlı olarak değişebilir. Fitoöstrojenler, vücutlarında düşük konsantrasyonda östrojen bulunan çocuk ve erişkin erkeklerde belirgin östrojenik etkiye neden olurken, yüksek konsantrasyonda östrojen bulunduran ergin dişilerde, kandaki östrojen ile yarışarak etkisini azaltabilirler $(7,19)$.

\section{Endokrin Bozucuların Sağlık Üzerine Etkileri}

Hormonlar, salgı bezleri tarafından üretilerek kana salınan ve özel hedef hücrelere etki eden bileşiklerdir. Endokrin sistem, hormonlar aracılığı ile, canlıların çeşitli metabolik fonksiyonlarını, hücredeki kimyasal tepkimelerin hızını, hücre membranından madde taşınmasını, hücrelerin farklılaşma, gelişme ve sekresyon yapma fonksiyonlarını kontrol edip aynı zamanda hormon salgılayan özel dokulara ait hücrelerdeki tepkimeleri çevresel uyaranlara göre regüle eder. Endokrin sistem beyinde hipofiz, hipotalamus ve endokrin bezlerden ibarettir. Bu sistem çeşitli görevleri yerine getiren farklı hormonları hassas oranda belirlenmiş düzeylerde üretir ve kana salgılar (20). Vücutta hormonal sistemin etkileri bazen saniyeler, günler, haftalar, bazen de yıllarca devam edebilir. Hormonların salınması esnasında konsantrasyon bazında meydana gelen dramatik azalış ve artışlar endokrin sistemde bozukluklara neden olabilir. Eğer hormon yeterli seviyede salgılanamıyorsa bu hormona ait fizyolojik etkiler az ya da hiç gözlenemezken aksi durumlarda etki aşırı olabilir $(20,21)$. Hormona özgü hedef hücreler hücre membranında bulunan protein yapıdaki spesifik reseptöre, ilgili hormonun bağlanmasını sağlar. Hormon-reseptör etkileşimi, hedef hücrenin aktivitesinin veya işlevinin değişmesini sağlayacak olan bir dizi kimyasal tepkimeyi başlatır (22).

Endokrin bozucular vücuda yiyecek, içecek, solunum ve deri yoluyla alınabilmekle birlikte (10) metabolitleri de özellikle hayvan ve insan hayatını olumsuz yönde etkileyerek fizyolojik değişikliklere neden olabilmektedir $(23,24)$.

Endokrin bozucuların canlılar üzerindeki olumsuz etkileri genellikle tiroid fonksiyonları ve üreme sistemi üzerinde meydana gelir $(25,26)$. Sentetik ve doğal endokrin bozucular hayatın pek çok alanında kullanılmaktadır. Bu kimyasallar hormonların üretiminden etkilerinin ortaya çıkışı ve metabolitlerinin vücuttan atılımına kadar her aşamada etkilerini gösterebilmektedir. Gündelik hayatımızda, tarımda ve endüstride kullanılan pek çok madde EBK içerir (27). Bu kimyasallar yumurtalık ve testis gelişimini sağlayan endokrin bezlerden, dişide üreme fonksiyonlarından, uterus gelişimine kadar hemen her aşamada etkilerini göstererek fizyolojik değişikliklere neden olurlar. Özellikle fetal dönemde bu kimyasallara maruz kalınması, üreme organlarında geri dönüşümü olmayan ciddi kusur ve hastalıklara sebep olabilir (28). Benzer olarak, neonatal dönem, canlıların endokrin bozuculara karşı en savunmasız kaldığı dönemdir. Örneğin, neonatal dönemde androjenik ilaç verilen sıçanların testis ağırlıklarında değişikliklerin olduğu bildirilmiştir (29). Bununla birlikte testislerde kanser riskinin arttığı, sperm sayılarının azaldığını gösteren çalışmalar da bulunmaktadır (30). Antiandrojenik ve östrojenik endokrin bozucular dişide rahim ile meme kanseri gelişiminde, erkekte ise prostat ve testis kanseri oluşumunda bir risk faktörü olarak değerlendirilmektedir $(31,32)$. EBK'lara gelişim dönemlerinde maruziyete bağlı olarak deney hayvanları ve insan çalışmalarında ortaya çıkan hastalıklar Tablo 1'de verilmiştir (33).

Tablo 1. EBK'lara gelişim dönemlerinde maruz kalmış olan deney hayvanları ve insan çalışmalarında ortaya çıkan hastalıklar. EBK MARUZIYETI

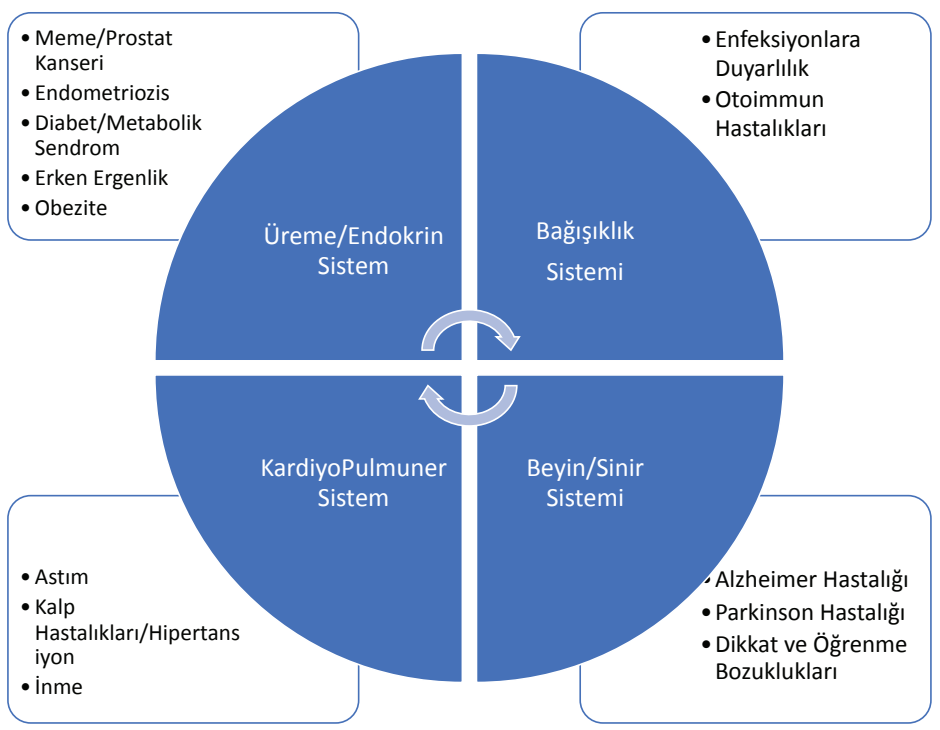




\section{Endokrin Bozucu Kimyasalların Günlük Hayatı- mızdaki Yeri}

Günümüzde EBK'lara doğada artık hemen her yerde rastlanabilmektedir. Endokrin bozucular günlük yaşamımızda kullandığımız plastik şişeler, plastik torbalar, metal yiyecek ve içecek kutuları, deterjanlar, oyuncaklar, yiyecekler ve kozmetik ürünlerinde bulunmaktadır. Bununla birlikte sanayi site atıkları, evsel ve hastane kaynaklı atıklar da bu kimyasallardan zengindir. Bu bölgelerden kaynaklanan atık sular, ileri biyolojik atık su arıtma tesislerinde çeşitli kademelerden geçtikten sonra bakterilerce biyolojik arıtılmaya tabi tutularak ya doğal ortama verilmekte ya da özel havuzlarda toplanarak yeniden kullanıma hazır hale getirilmektedir. Eğer atık sular etkin bir şekilde arıtılmaz ise endokrin bozucuların akarsu, deniz, göller ve toprak aracılığı ile insan, bitki ve hayvanlarla teması kaçınılmaz olur. Bu konuyla ilgili literatürde pek çok çalışma bulunmaktadır (34-36).

Ingiltere'de çeşitli bölgelerdeki atık su arıtma tesislerinin çıkış sularında $17 \beta$-östradiol, östron ve sentetik östrojen türevi olan $17 a$-etinilöstradiol tespit edilmiştir. Bununla birlikte atık suların deşarj edildiği göl ve nehirlerde yaşayan çeşitli deniz canlıları ve balıkların üreme sistemlerinde bozukluklar rapor edilmiştir (37). Östrojenlerin balıklarda farklılaşma ve büyüme süreçlerinde, cinsiyet belirlenmesinde; insanlarda ise içme suyuna karışan endokrin bozucuların sperm yoğunluğu, sperm sayısı ve hareketliliğinin azalması, erkekte jinekomasti gibi etkilerinin olduğu ortaya konmuştur. Bununla bağlantılı olarak Almanya, Kanada, İngiltere,
İsveç ve Türkiye'deki çalışmalarda ilaç bileşimlerindeki östrojen ve metabolitlerinin kanalizasyon sularının karıştığı akarsu ve nehirlerde bol miktarlarda tespit edildiği rapor edilmiştir (35,38-40).

\section{Endokrin Bozucu Kimyasalların Tekstil Endüstri- sinde Kullanımı}

\section{Bisfenol A}

Bisfenol A, ilk olarak 1891 yılında keşfedilmiştir. Endokrin etkileri ise 1930 'lardan beri bilinmektedir. BFA, endüstriyel alanda pek çok tüketici ürünlerinin imalatında kullanılan endokrin bozucu özellikteki plastizer bir maddedir. Plastiklerdeki polimerizasyon tepkimelerinde yer alır. Oyuncaklarda, kozmetik ürünlerde, ilaçlarda, biberonlarda, yiyecek ve içecek kaplarında, konserve kutu iç yüzeylerinde ve diş dolgu malzemelerinde kullanılan BFA'nın insan sağlığına olumsuz etkilerinin olduğu bildirilmiştir. BFA'nın pH, sıcaklık gibi bazı etmenler sonucu plastik kapların iç yüzeyindeki polimerlerden kap içinde bulunan sıvı ortama göç edebildiği gösterilmiştir $(41,42)$. Özellikle son 10 yılda dünya genelinde kız çocuklarının ergenliğe giriş yaşının öne kaydığının ve artan meme kanseri vakalarının ortaya konması ile beraber östrojenik etkisi kanıtlanmış bir çevresel endokrin bozucu olan BFA'nın her geçen gün önemi daha da artmaktadır (43-46). Bununla birlikte BFA'nın östrojen benzeri etki gösterebildiği, beyinde cinsel farklılaşmadan sorumlu bölgede deformasyona sebep olabileceği ileri sürülmüş ve öğrenme ile ilgili defektlere neden olduğu ortaya konmuştur (47). BFA maruziyetinin etkileri Şekil 2'de özetlenmiştir.

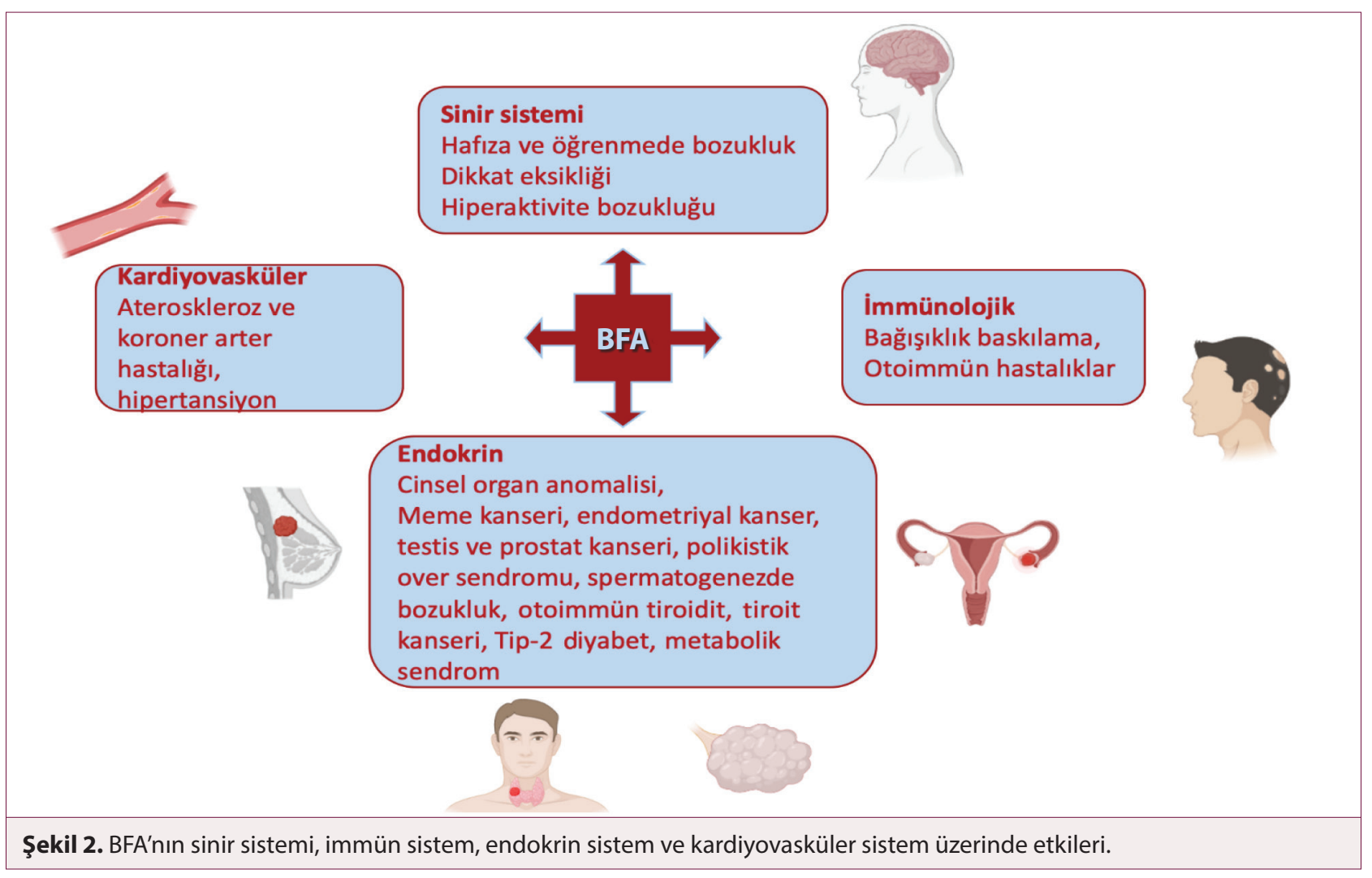


İnsan vücuduna oral yolla alındıktan sonra BFA, büyük oranda karaciğer ve bağırsakta çözünebilir metaboliti olan bisfenol A-glukronide dönüştürülür. Sonrasında ise bisfenol A-glukronid yaklaşık 6 saat kadar sonra renal yolla atılır (48). BFA maruziyetinin tek yolu oral yol olmamakta, inhalasyon ve deri yoluyla da vücuda giriş yapabilmektedir. BFA maruziyeti çoğunlukla kronik dönemde ve düşük dozla gerçekleşir. Özellikle son yıllarda insanoğlu geri dönüşüme tabi tutulmuş plastik şişelerde, cidarı epoksi reçine ile kaplanmış teneke kaplarda ve polikarbonat materyalden yapılmış kutuların içine BFA'nın geçiş yaptığı içecek ve yiyecekleri tüketerek bu endokrin bozuculara maruz kalmaktadır $(49,50)$.

Bunun yanı sıra BFA sentetik üretilen ksenoöstrojenler içinde önemli bir yer teşkil eden, insan yapımı ve yıllık üretimi neredeyse 3.8 milyon tonu geçen bir kimyasaldır (51). Yapılan deneysel araştırmalar BFA'nın östrojen reseptörüne bağlanıp östrojeni taklit ettiğini ortaya koymuştur (52). In vitro modellerde BFA'nın kromozom sayılarında değişikliklere, nükleik asitlerde serbest radikal hasarına ve mutajenik etkilere sebebiyet verdiği bildirilmiştir. BFA'nın DNA'ya verdiği hasar canlı türlerinde kısırlığa, doğumsal anomalilere ve düşüklere neden olur. Nitekim bir deneysel modelde içme sularına BFA katılan sıçanlarda meme dokularından ekstrakte edilen hücrelerin DNA moleküllerinde ve protein yapılarında serbest radikal kaynaklı protein hasarı olduğu bildirilmiştir (53).

BFA vücutta etkilerini çeşitli şekillerde gösterir. Bunlar BFA'nın hem nükleer östrojen reseptörüne hem de membran östrojen reseptörüne bağlanması ve genomik olmayan yolaklara entegrasyonuyla meydana gelir. BFA'nın bu etkileri meme bezi, yumurtalık, beyin gibi östrojenin hedef organlarında fizyolojik birtakım değiş̧ikliklere sebep olur. Literatürde BFA'nın oksidatif hasara da neden olduğu bildirilmektedir. Bu etkiyi mitokondri elektron transport sisteminin çalışmasını bozarak ve antioksidan enzimleri inaktive ederek gerçekleştirir $(54,55)$.

BFA'nın sağlık üzerine olumsuz pek çok etkisi sebebiyle kullanımına kısıtlamalar ve yasaklar getirilmesi sağlık otoriteleri ve bilim dünyası tarafından yıllardan beri gündem konusu olmaya devam etmektedir. Amerikan Ulusal Toksikoloji Programı (NTP) 2008 yılında hazırladığı raporda fetüs, çocuk ve yetişkin bireylerdeki BFA maruziyetinin üreme, sinir sistemi ve davranış üzerine etkilerine dair endişelerini kamuoyuyla paylaşmış, 2010'da Amerikan Gıda ve İlaç Dairesi (FDA) de NTP gibi durumun önemine dikkatleri çekmiştir. Yapılan bu açıklamalardan sonra Kanada Hükümeti yetkilileri BFA içeren bebek biberonlarının ithalatına ve satışına yasak getirdiğini açıklamış, Avrupa Komisyonu da 2011 yılında polikarbonat ihtiva eden şişe üretiminde BFA kullanımını sınırlandırmıştır $(56,57)$. Daha sonra FDA Amerikan Kimya Birliğinin taleplerine cevap olarak BFA ihtiva eden biberonların kullanılmasını 2012 yılında kesin olarak yasaklamıştır. FDA, yapısında BFA ihtiva eden reçinelerin kutu içi içecek kaplamalarda kullanılmasını ise 2013'de aldığı kararla yasaklamıştır (58). Türkiye'de Avrupa Komisyonunun beslenme şişeleri üretimindeki BFA kullanımını ciddi bir şekilde sınırlandırma kararıyla koşut olarak Tarım Köy İşleri Bakanlığı́nca 2011 yılı Haziran ayında BFA ihtiva eden biberonlar ve benzeri beslenme gereçleri piyasadan geri çektirilip toplatılmıştır (59).
Pek çok bilimsel kuruluş insan sağlığı açısından tehlikeli bir molekül olan BFA'nın toksisitesiyle ilgili çeşitli değerlendirmelerde bulunmuştur. Bu kuruluşlardan biri olan Avrupa Gıda Güvenliği Otoritesi (EFSA), çeşitli platformlarda 2006 yılından beri düzenli olarak BFA hakkında bilimsel görüşlerini açıklamaktadır. Bu kuruluş 2015 yılında düzenlediği panelde BFA'nın diyetle, ev tozu ile, termal kağıttan ve kozmetiklerden günde $4 \mu \mathrm{g} / \mathrm{kg}^{\prime} / \mathrm{lk}$ miktara kadar vücuda alımını "tolere edilebilir değer" (t-TDI) olarak deklare etmiştir. Ancak bu değerin vücuda alım ile ilgili sabit bir değer olmaması gerektiği de ileri sürülmektedir. Bunun nedeni BFA'nın yukarıda belirttiğimiz kaynaklarının yanı sıra farklı kaynaklarının da olabileceğidir. Son yıllarda yapılan çalışmalara göre bu kaynaklardan biri tekstil sanayidir. Ne yazık ki günümüzde tekstil sanayisinde BFA kullanımına ilişkin doğrudan bir kısıtlama yoktur. Ülkemizde bu doğrudan kısıtlama henüz yokken Avrupa Birliği ülkeleri “Ecolabel 66/10" denetimi altındadır. Bunun nedeni, BFA'nın "Çok Yüksek Önem Arz Eden Maddeler (SVHC)" listesine dahil edilmesine karşın, Avrupa Birliği Çevre Etiketi yalnızca ağırlıkça \%0,1'den fazla SVHC içermeyen tekstil ürünlerine verilmektedir (60).

Geçtiğimiz birkaç yıla kadar BFA'nın sadece polikarbonat, epoksi reçineler ve termal kağıtlarda bulunduğu düşünülmekteydi. Bu nedenle BFA'nın tekstil sanayindeki maruziyet senaryoları veya toksisitesi ile ilgili yapılan değerlendirmeler hiçbir zaman bir tehlike unsuru olarak görülmedi (61). Ancak son yıllarda, tekstil sanayinde bazı ürünlerde BFA'nın varlığı tespit edilmiş ve beraberinde de bazı maruziyet çalışmaları yapılmaya başlanmıştır. 2017 ve 2018 yıllarında Avrupa Birliği dışındaki çeşitli ülkelerden alınan kumaş örnekleri üzerinde yapılan araştırmalarda bazı bebek çoraplarında ve kadın külotlu çoraplarında BFA'nın tespit edildiği bildirilmiştir. Ayrıca son zamanlarda (Nisan 2019) Avrupa pazarlarından alınan bebek ve küçük çocuk çorap örneklerinde BFA'nın varlığı ve endokrin bozucu aktivitesi gösterilmiştir (62-64).

$\mathrm{Bu}$ veriler giyim eşyalarının ciltle doğrudan ve uzun süreli temas halinde olması nedeniyle endişe vericidir. Bu endişe, tekstil ürünlerinde tespit edilen, bunların deri ile temas yoluyla vücuda alınması sonucu idrarda da görülen, sadece östrojenik ve anti-androjenik etkileri nedeniyle değil, aynı zamanda bebek ve küçük çocukların genellikle çorap ve kıyafetlerini ağızlarına sokmaları ve emmeleri suretiyle bu EBK'ları bünyelerine almaları ile de ilgilidir. Benzer şekilde, hamile kadınların da bu kimyasallara maruz kalma ihtimali, fetüs üzerindeki olası potansiyel etkileri nedeniyle de endişe verici boyutlardadır (65).

Dolayısıyla bebekler, küçük çocuklar ve hamile kadınların kullandığı tekstil ürünlerindeki BFA'nın zararlı etkilerinin bertaraf edilmesini sağlamaya yönelik kısıtlı yasa ve yönetmelikler, bu kimyasalların neden olabileceği sağlık ve çevre problemleri ile ilgili yaptırımların ortaya konulmasında birtakım zorluklara neden olacaktır (65).

Tekstil endüstrisinde elyaf, iplik ve nihai kumaş üretimi aşamasında çeşitli kimyasallar kullanılmaktadır. Şeffaflık Piyasası Araştırma Firması tarafından 2015 yılında yapılan bir çalışma, tekstil kimyası pazarının küresel anlamda 21 milyar dolar olan mevcut 
$A B D$ piyasa değerinin yıllık \%3,7 büyümesinin beklendiğini ortaya koymuştur. Her yıl tekstil kimyası pazarının bu boyutlarda büyümesi canlı sağlığı bakımından endişe vericidir. Bununla birlikte tekstil endüstrisi tarafından üretilen nihai kumaşların \%100 doğal liflerden yapılmış olmaları durumunda bile yaklaşık \%27 (ağırlıkça) kimyasal içerdiği tahmin edilmektedir. Üretimde sentetik lifler kullanılması durumunda ise beraberinde yüksek miktarda kimyasal kullanımı da gerçekleşecektir. Bunun sonucunda da canlıların bu kimyasallara maruziyetleri artacaktır (66).

Kumaş üretiminde kullanılan kimyasallar tekstil yardımcıları, tekstil kimyasalları ve apre olarak kategorize edilir. Tekstil yardımcıları doğal liflerin saflaştırılmasında kullanılır. Tekstil kimyasalları, kumaş üretiminde kullanılan boyaları ve UV ışık emicilerini barındıran kimyasallardır. Kumaşın doğal özelliklerini daha da iyileştirmek ve ömrünü uzatmak amacıyla ise tekstil apreleri uygulanır. Bu işlemde, oksidasyonun önlenmesi ve tekstil materyalinin bozulmasının engellenmesi adına antioksidan katkılar kullanılır. BFA ve türevleri bu antioksidanların ve tekstil boyalarının üretiminde ara kimyasal olarak kullanılmasının yanı sıra tekstil endüstrisinde işleme aşamasında da kullanılır. Örneğin, polyester kumaşların üretiminde apre olarak $\% 5$ polietilen glikol bisfenol A eter diakrilat kullanımı rapor edilmiştir. Bununla birlikte sentetik deri üretiminde kullanılan plastisol polivinil klorür (PVC) baskılar, tekstil üretiminde önemli bir BFA kaynağıdır. Benzofenoller de tekstilde güneş ışı̆̆ından kaynaklanan oksidatif hasarı önlemek amacıyla kullanılır (67-69).

Kullanımları oldukça yaygın olmasına rağmen, EBK'ların tekstil ürünlerindeki konsantrasyonları yakın zamana kadar detaylı bir şekilde araştırılmamıştır. Günlük yaşamda sıklıkla kullandığımız giysi ve yatak nevresimi gibi tekstil ürünlerinin derinin epidermisi ile teması neticesinde insanlar bu kimyasallara maruz kalmaktadır. Bununla birlikte bebekler de bazı bebek bezlerinde bulunan endokrin bozucular yüzünden risk altındadır (70).

Literatürde kumaş ve giysilerdeki BFA düzeyleri ile ilgili fazla çaIışma bulunmamaktadır. Xue ve arkadaşlarının (62) çalışmasında çeşitli çocuk tekstil ürünlerinde BFA konsantrasyonları ölçül- müştür. En yüksek BFA konsantrasyonu 6-12 aylık bebekler için üretilen $\% 97$ polyester malzemeden yapılmış gri renkli çoraplarda $13300 \mathrm{ng} / \mathrm{g}$ olarak tespit edilmiştir. BFA doğrudan tekstil üretiminde kullanılmamaktadır, ancak kumaş boyaları da dahil olmak üzere tekstil üretiminde kullanılan çeşitli ara ürünler BFA kaynağı olabilir. Örneğin, polietilen glikol bisfenol A eter diakrilat günümüzde polyester kumaşların üretimine bir kimyasal olarak katılmaktadır. Çalışmadaki çorapların büyük kısmı \%97-98 polyester kumaştan yapılmıştır. Son yıllarda polietilen ve polikarbonattan üretilen geri dönüştürülmüş plastik şişeler, polyester fibere dönüştürülerek çorap ve giysi üretiminde kullanılmaktadır. Bu nedenle, polyester içeren çoraplarda bulunan BFA'nın kaynağı polyester üretiminde hammadde olarak kullanılan geri dönüştürülmüş plastik şişelerdir. Medyada tüketim mallarında BFA kullanımına ilişkin artan endişeler nedeniyle, bisfenol $\mathbf{S}$ (BFS) kullanımı BFA içermeyen bir alternatif olarak sunulmuştur. Ancak çalışmalar, BFS'nin BFA'dakilere benzer genotoksisite ve östrojenik aktiviteye sahip olduğunu göstermiştir $(68,70,71)$.

\section{Fitalatlar}

Plastiklere şeffaflık, esneklik ve dayanıkılık kazandırmak üzere üretilen fitalatlar "sentetik kimyasallar" grubuna girer. Dietilheksil fitalat (DEHP) sanayide en fazla kullanılan fitalat türü olmakla birlikte genel olarak vinil içeren ürünlerde yumuşatıcı ve akışkanlık sağlayıcı, polimer endüstrisinde de çözücü olarak kullanılmaktadır. Global olarak senede ortalama 3 milyon ton fitalat işlenmektedir $(72,73)$.

Polimerlere plastikleştirici olarak ilave edilen fitalatlar, bu yapılara kovalent olarak bağlanamamalarından dolayı çeşitli ürünlerin yüzey tabakalarından kolaylıkla göç edebilme yeteneğindedirler. Böylelikle çevresel etkenler nedeniyle havaya karışabilir ve BFA'da olduğu gibi bulundukları kaplardaki sıvıların içine göç edebilirler. Fitalatlar, insan ve diğer canlıların sağlığını bu yollarla tehdit ederken aynı zamanda çevre kirliliğine de neden olur. Bu yollarla insanoğlu istemeden ve farkında olmadan yoğun bir şekilde bu kimyasallara maruz kalır $(74,75)$. Fitalatların toksik etkilerinin mekanizması Şekil 3'te özetlenmiştir.

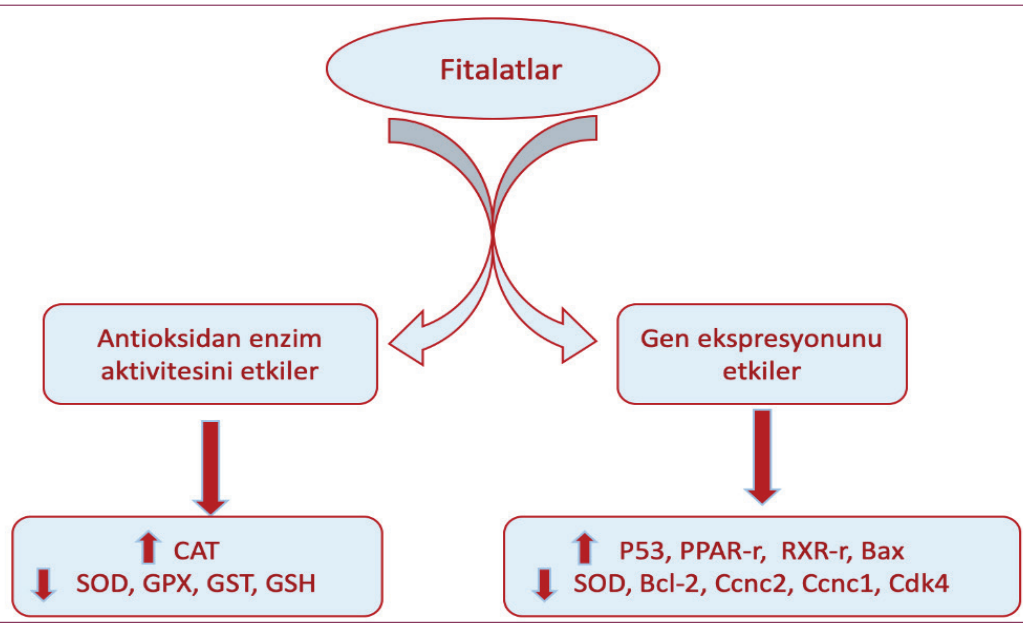

Şekil 3. Fitalatlar gen ekpresyonu ve antioksidan enzim aktivitesini etkileyerek toksisiteye neden olur. 
Günümüzde doğada her yerde karşımıza çıkan plastik ürünlerde bulunan fitalatların deri, sindirim ve solunum sistemi yoluyla vücuda alınarak insan sağlığı üzerine olan etkilerinin kapsamlı bir şekilde ortaya konması önem arz eden bir konudur. Öncelikle BFA üzerine odaklanan çoğu araştırıcı son yıllarda fitalat ve fitalat esterlerinin canlı sağlığı üzerine olan olumsuz etkilerine odaklanmıştır. Fitalat esterlerinin yarılanma ömürleri kısadır. Bu moleküller monoesterlere, glukronik konjugatlara ve ileri oksidasyon ürünlerine bağlanabilir ve daha sonra idrarla atılır (76). Fitalat metabolitlerinin anne sütü, amniyotik sıvı, insan tükürüğü gibi biyolojik sıvılara geçişi yapılan çalışmalarda gösterilmiştir (77). Fitalatlar endokrin sisteme zarar verir ve hücrede reseptöre bağlanmak suretiyle endokrin sistem üzerinde çeşitli etkilere neden olur (78). Fitalat esterlerinin gonadlar, karaciğer ve böbrekler üzerine zararlı etkileri hayvan modelleri üzerinde yapılan araştırmalarda ortaya konmuştur (79).

Fitalatlar gündelik hayatta çeşitli kullanım alanlarına sahiptir. Öyle ki bazı plastik malzemeler \%40'a kadar DEHP içerebilir. DEHP sentetik deride, suya dayanıklı tekstil malzemesi imalatında, ayakkabı, kablo, teflon tava, döşeme, ambalaj malzemesi, çocuk oyuncakları, kauçuk, alüminyum folyo ve çeşitli tipteki kimyasal çözücüde bulunur. Bununla birlikte bazı medikal malzemelerde de DEHP varlığı tespit edilmiştir. Ayrıca uzun yan zincirlere sahip olan fitalatlar endüstriyel yağlarda, sıvı deterjan ürünlerinde, kağıt imalatında ve pestisit üretiminde ek malzeme olarak kullanılmaktadır $(80,81)$. Kısa zincir içeren fitalatlar ise makyaj malzemelerinde, kişisel bakım ürünlerinde, sabun, parfüm, boya, yapıştırıcılarda ve enterik kaplı tabletlerde bulunmaktadır $(82,83)$.

Fitalatlar nefes alma suretiyle, oral yolla ve deri yoluyla vücuda girebilir. Bununla birlikte diğer fitalat maruziyet yolları arasında kan transfüzyonu, diyaliz torbası ve sonda gibi medikal malzemelerin kullanımı bulunmaktadır $(84,85)$. Bir diğer dikkate değer maruziyet yolu ise kapı ve pencere imalatında kullanılan PVC malzemelerdir (86). Bu sebepten dolayı çoğunlukla iç mekan hava fitalat konsantrasyonu dış mekanlara göre daha yüksektir. Ayrıca şehirleşmenin başladığı bölgelerde açık alanlardaki fitalat konsantrasyonu kırsal bölgelerle karşılaştırıldığında daha yüksek olarak tespit edilmiştir $(87,88)$. Fitalat içeren kaplarda saklanan yiyecek ve içecekler vasıtasıyla da maruziyet mümkündür. Özellikle fitalat ihtiva eden içecek ve yiyecek kaplarının mikrodalga fırınlarda yüksek watt değerlerinde ısıtılması neticesinde bu maruziyet çok daha fazla gerçekleşmektedir (89).

Serum fitalat konsantrasyonunun artışı ile birlikte kalp ve damar hastalıkları riskinin belirgin şekilde arttığı bildirilmektedir (90). Bebek ve küçük çocukların oyuncak ve tekstil ürünlerini sıklıkla ağızlarına götürmeleri, vücut su yüzdelerinin fazla olması ve yüksek metabolik hıza sahip olmaları nedeniyle bu kimyasallardan yetişkinlere göre daha çok etkilenirler. Bu etkilenme hayvan çalışmalarında da açıkça ortaya konmuştur. Gebe hayvanlarda DEHP maruziyeti teratojenik ve gelişimsel defektlerle sonuçlanmıştır (91-93). Deney hayvanlarıyla yapılan çalışmalarda fitalatların böbrek, akciğer ve karaciğer gibi organlar başta olmak üzere özellikle üreme sistemi üzerinde toksik ve karsinojen etki yaptığı bildirilmiştir. Avrupa birliği öncelikli olarak iki tür fitalatı (DEHP ve Dibütil fitalat (DBP)) üreme açısından toksik olarak sınıflandırmıştır (94).

Pedersen ve Hartmann'ın (95) yaptığı çalışmada kullanılan kumaşların baskılı olan bütün kısımlarında fitalat tespit edilse de miktarlar baskı üzerindeki yerine göre önemli oranda değişmektedir. Danimarka'da bir mağazadan alınan Tigger yeleğinin baskılı bölümü toplamda 1,4 mg/kg fitalat içeriğine sahipken, Slovak menşeili Tigger önlük numunesinin toplamda 200 mg/ kg fitalat içerdiği bulunmuştur (numunenin ağırlığının \%20 'sinden fazlası). Hollanda'dan alınan Donald Duck tişört baskısı ise $170.036 \mathrm{mg} / \mathrm{kg}$ toplam fitalat içermektedir (numunenin ağırlıkça \%17'sinden fazlası). Bu sonuçlar, giysilerin PVC bazlı plastisol baskılarla basılmış olabileceğini düşündürmektedir. Belçika, Kanada, Norveç, Çin, İspanya ve ABD'den gelen giysilerden alınan baskı numuneleri, 42 ile $101 \mathrm{~g} / \mathrm{kg}$ (ağırlıkça \%4 - \%10 arasında ve yüksek oranda) seviyelerde fitalat içerirken, diğer 6 adet farklı baskı numunesinde ise 0,1 gramdan daha az fitalat içeriği bulunmuştur. Almanya'da satın alınmış olan PVC Winnie the Pooh yağmurlukta tespit edilen fitalat düzeyleri ise $320 \mathrm{mg} / \mathrm{kg}$ olarak tespit edilmiştir. Yapılan çalışmaların sonuçlarına göre numunelerde bulunan kimyasalların türü ve miktarında farklılıkların olduğu görülmektedir. Bu araştırmada tespit edilen başlıca fitalatlar DEHP, benzil-butil fitalat (BBP), diisononil fitalat (DINP) ve diheptil fitalat (DHP)'tır. ABD'den satın alınmış giysilerde tanımlanamayan fitalatlar da tespit edilmiştir. Belçika ve Slovakya'dan alınan örnek kıyafetlerin baskılı kısımlarının ise çok yüksek miktarlarda fitalat içerdiği bulunmuştur. Bu giysilerde muhtemelen PVC bazlı plastisol baskıların kullanıldığı düşünülmektedir (95).

Tekstil ürünlerinde bulunan fitalatlar, kullanıcılarının bu ürünleri yıkamaları neticesinde doğayı tehdit eder hale gelmektedir. Atık sulara karışan fitalatlar atık su arıtma tesisleri veya kanalizasyon yoluyla akarsu, göl ya da denizlere deşarj edilerek doğaya salınmakta, buralarda yaşayan türlerin varlığını tehdit etmekte ve çevre kirliliğine neden olmaktadır (94-95).

\section{SONUÇ}

EBK'ların sağlık üzerindeki olumsuz etkileri literatürdeki birçok araştırmada gözler önüne serilmiştir. Bilim ve teknolojinin bu kadar hızlı ilerlediği bir çağda bugüne kadar varlığı tespit edilen ve henüz tespit edilmemiş olan bu kimyasallara maruz kalmamak imkansız gibi görünmektedir.

Endokrin bozucular hücrenin yağ dokusunda depolanabilirler. Bu sebeple EBK'ların çevre ve toplum sağlığı üzerindeki etkilerini minimuma indirmek adına sıkı önlemlerin alınması elzemdir. Öncelikli olarak tarladan mutfağımıza gelen sebze ve meyvelerin iyi bir şekilde yıkanarak pestisit ve herbisitlerden arındırılmasına özen gösterilmeli, atık suların deşarj edildiği akarsu, göl ve denizlerde yaşayan canlıların tüketilmesinden kaçınılmalı, bu kimyasalları içeren çeşitli ilaçlar, saklama kapları, su damacanaları, pet şişeler, biberon, bebek oyuncakları, tekstil ürünleri ve kozmetik ürünler gibi tüketim mallarının kullanımı durdurulmalı, ithalatına ve üretimine sınırlamalar getirilmeli, 
konu ile ilgili yeni yasa ve yönetmelikler acilen çıkarılmalı, yürürlüğe konulmalıdır. Endokrin bozucuların insan sağlığı üzerine olan etkilerini minimum seviyeye indirgemek için yaşam tarzımızın ve alışkanlıklarımızın ciddi bir şekilde gözden geçirilmesi gerekmektedir. Endokrin bozucu mekanizmaların daha iyi anlaşılabilmesi için çok daha fazla sayıda bilimsel araştırmaya gereksinim duyulmaktadır.

\section{Hakem Değerlendirmesi: Dış bağımsız.}

Yazar Katkıları: Çalışma Konsepti - A.A.A.; Veri Toplama - L.T., D.C., E.E.A., A.A.A.; Veri Analizi/Yorumlama - E.E.A., Yazma - L.T., D.C.

Çıkar Çatışması: Yazarlar çıkar çatışması bildirmemişlerdir.

Finansal Destek: Yazarlar bu çalışmada finansal destek almadıklarını beyan etmişlerdir.

Peer-review: Externally peer-reviewed.

Author Contributions: Concept - A.A.A.; Data Collection - L.T., D.C., E.E.A., A.A.A.; Analysis and/or Interpretation - E.E.A.; Writing - L.T., D.C.

Conflict of Interest: The authors have no conflict of interest to declare.

Financial Disclosure: The authors declared that this study has received no financial support.

\section{KAYNAKLAR/REFERENCES}

1. Goldman JM, Laws SC, Balchak SK, Cooper RL, Kavlock RJ. Endocrine-disrupting chemicals: pre-pubertal exposures and effects on sexual maturation and thyroid activity in the female rat. A focus on the EDSTAC recommendations. Crit Rev Toxicol 2000; 30: 13596. [CrossRef]

2. Zafra-Gómez A, Ballesteros O, Navalón A, Vílchez JL. Determination of some endocrine disrupter chemicals in urban wastewater samples using liquid chromatography-mass spectrometry. Microchemical Journal 2008; 88(1): 87-94. [CrossRef]

3. Khetan SK. Environmental Chemicals Targeting Estrogen Signaling Pathways. Endocrine Disruptors in the Environment. 1st Edition. Hoboken, New Jersey: John Wiley \& Sons, Inc.; 2014.p.67-8.

4. Lee MM. Endocrine Disrupters. A Current Review of Pediatric Endocrinology 2007; 109-18.

5. Kumar A, Kumari C, Mochan S, Kulandhasamy M, Sesham K, Sharma VK. Endocrine System. In:Vonk J, Shackelford T, editors. Encyclopedia of Animal Cognition and Behavior. Springer, Cham 2018; p.1-26. [CrossRef]

6. Büyüktuncer Z, Başaaran A. Fitoöstrojenler ve Sağlıklı Yaşamdaki Önemleri. Hacettepe Üniversitesi Eczacılık Fakültesi Dergisi 2005; 25(2): 79-94.

7. Jarvis E, Campbell NA, Reece JB. Hormones and the Endocrine System. Wilbur B. Biology. San Francisco: Pearson Education 2005.p.9456.

8. Wuttke W, Jarry H, Seidlova-Wuttke D. Definition, classification and mechanism of action of endocrine disrupting chemicals. Hormones (Athens) 2010; 9(1): 9-15. [CrossRef]

9. Colborn T, vom Saal FS, Soto AM. Developmental effects of endocrine-disrupting chemicals in wildlife and humans. Environ Health Perspect 1993; 101(5); 378-84. [CrossRef]
10. Chang HS, Choo KH, Lee B, Choi SJ. The methods of identification, analysis, and removal of endocrine disrupting compounds (EDCs) in water. J Hazard Mater 2009; 172(1): 1-12. [CrossRef]

11. Metzler M, Pfeiffer E. Chemistry of Natural and Anthropogenic Endocrine Active Compounds. In: Metzler M editor. The Handbook of Enviromental Chemistry, Endocrine Disruptors Part 1. Springer-Verlag Berlin Heidelberg; 2001. p.63-80. [CrossRef]

12. Ward WE, Thompson LU. Dietary Estrogens of Plant and Fungal Origin: Occurrence and Exposure. In: Metzler M editor. The Handbook of Enviromental Chemistry, Endocrine Disruptors Part 1. Springer-Verlag Berlin Heidelberg; 2001.p.101-28. [CrossRef]

13. Toppari J, Larsen JC, Cristiansen P, Giwercman A, Grandjean P, Guillette $L J$, et al. Male reproductive health and enviromental xenoestrogens. Environmental Health Perspectives 1996; 104: 741-803. [CrossRef]

14. Bigsby R, Chapin RE, Daston GP, Davis BJ, Gorski J, Gray KL, et al. Evaluating the effects of endocrine disruptors on endocrine function during development. Environmental Health Perspectives 1999; 107: 613-8. [CrossRef]

15. Kuwada M, Kawashima R, Nakamura K, Kojima H, Hasumi H, Maki J. Study of neonatal exposure to androgenic endocrine disruptors, testosterone and dihydrotestosterone by normal-phase HPLC. Biomed Chromatography 2006; 20: 1237-41. [CrossRef]

16. Carlsen E, Giwercman A, Keiding N, Skakkebaek NE. Evidence for decreasing quality of semen during past 50 years. BMJ 1992; 305: 609-13. [CrossRef]

17. McLachlan JA, Simpson E, Martin M. Endocrine disrupters and female reproductive health. Best Pract Res Clin Endocrinol Metab 2006; 20: 63-75. [CrossRef]

18. Bergman A, Heindel JJ, Jobling S, Kidd KA, Zoeller RT. WHO, State of the science of endocrine disrupting chemicals: Summary for decision makers. DTI/1554/GE, 2012. [CrossRef]

19. Laganà A, Bacaloni A, De Leva I, Faberi A, Fago G, Marino A. Analytical methodologies for determining the occurrence of endocrine disrupting chemicals in sewage treatment plants and natural waters. Analytica Chimica Acta 2004; 501(1)9; 79-88. [CrossRef]

20. Çek Ş, Sarıhan F. Endokrin Sistemi Bozan Kimyasallardan Cinsiyet Steroidlerinin Balıklardaki Etkileri. E.U. Journal of Fisheries \& Aquatic Sciences 2010; 27(1); 41-6.

21. Beszterda M, Frański R. Endocrine disruptor compounds in environment: As a danger for children health. Pediatr Endocrinol Diabetes Metab 2018; 24(2): 88-95. [CrossRef]

22. Hemming JDC, Barman MAE, Standridge JH. Assessment of Source and Drinking Waters for Estrogenic Endocrine Disruption, AWWA WQTC Conference 2001.

23. Matthiessen P. Endocrine disruption in marine fish. Pure Appl Chem 2003; (75)11-12: 2249-61. [CrossRef]

24. Turan F, Çek Ş. "Masculinization of African Catfish (Clarias gariepinus) treated with Gokshura (Tribulus terrestris)", The Israeli Journal of Aquaculture- Bamidgeh 2007; 59(4): 224-9.

25. Sharp RM, Skakeabeak NE. Are estrogens involved in falling sperm counts and disorders of the male reproductive tract? Lancet 1993; 41: 1392-5. [CrossRef]

26. Wazir U, Mokbel K. Bisphenol A: A Concise Review of Literature and a Discussion of Health and Regulatory Implications. In Vivo. 2019; 33(5): 1421-3. [CrossRef]

27. Cooper JE, Kendig EL, Belcher SM. Assessment of bisphenol A released from reusable plastic, aluminium and stainless steel water bottles. Chemosphere 2011; 85(6): 943-7. [CrossRef]

28. Yang $Y$, Wang Z, Xie S. Aerobic biodegradation of bisphenol A in river sediment and associated bacterial community change. Sci Total Environment 2014; 470-471: 1184-8. [CrossRef] 
29. McGuinn LA, Ghazarian AA, Joseph S, Ellison GL. Urinary bisphenol $A$ and age at menarche among adolescent girls: evidence from NHANES 2003-2010. Environ Res 2015; 136: 381-6. [CrossRef]

30. Rhie YJ, Nam HK, Oh YJ, Kim HS, Lee KH. Influence of bottle-feeding on serum bisphenol a levels in infants. J Korean Med Sci 2014; 29(2); 261-4. [CrossRef]

31. Paulose T, Speroni L, Sonnenschein C, Soto AM. Estrogens in the wrong place at the wrong time: Fetal BPA exposure and mammary cancer. Reprod Toxicology 2015; 54: 58-65. [CrossRef]

32. MacLusky NJ, Hajszan T, Leranth C. The environmental estrogen bisphenol-A inhibits estrogen-induced hippocampal synaptogenesis. Environ Health Perspect 2005; 113: 675-9. [CrossRef]

33. Volkel W, Colnot T, Csanady GA, Filser JG, Dekant W. Metabolism and kinetics of bisphenol a in humans at low doses following oral administration. Chem Res Toxicol 2002; 15(10): 1281-7. [CrossRef]

34. Bloom MS, Mok-Lin E, Fujimoto VY. Bisphenol A and ovarian steroidogenesis. Fertil Steril 2016; 106(4): 857-63. [CrossRef]

35. Vandenberg LN, Mafni MV, Sonnenschein C, Rubin BS, Soto AM. Bisphenol-A and the great divide: a review of controversies in the feld of endocrine disruption. Endocr Rev 2009; 30(1): 75-95. [CrossRef]

36. Michalowicz J. Bisphenol A - Sources, toxicity and biotransformation. Environ Toxicol Pharmacol 2014; 37: 738-58. [CrossRef]

37. Lee HS, Parka EJ, Oha JH, Moona G, Hwanga MS, Kima SY, et al. Bisphenol A exerts estrogenic effects by modulating CDK1/2 and p38 MAP kinase activity. Biosci Biotechnol Biochem 2014; 78(8): 1371-5. [CrossRef]

38. Izzotti A, Kanitz Z, D'Agostini F, Camoirano A, De Flora S. Formation of adducts by bisphenol $A$, an endocrine disruptor, in DNA in vitro and in liver and mammary tissue of mice. Mutat Res/Genet Toxicol Environ Mutagen 2009; 679: 28-32. [CrossRef]

39. Rezg R, El-Fazaa S, Gharbi N, Mornagu B, Rezg R. Bisphenol A and human chronic diseases: Current evidences, possible mechanisms, and future perspectives. Environ Int 2014; 64: 83-90. [CrossRef]

40. Moon MK, Kim MJ, Jung IK, Koo YD, Ann HY, Lee KJ, et al. Bisphenol A impairs mitochondrial function in the liver at doses below the no observed adverse effect level. J Korean Med Sci 2012; 27(6): 644-52. [CrossRef]

41. Rezg R, El-Fazaa S, Gharbi N, Mornagui B. Bisphenol A and human chronic diseases: current evidences, possible mechanisms, and future perspectives. Environ Int 2014; 64: 83-90. [CrossRef]

42. EFSA, Report on the two-phase public consultation on the draf EFSA scientifc opinion on bisphenol A (BPA). Retrieved from Parma ITALY 2015 http://www.efsa.europa.eu/sites/default/fles/ scientifc_output/fles/main_documents/740e.pdf.

43. Usman A, Ahmad M. From BPA to its analogues: Is it a safe journey? Chemosphere 2016; 158: 131-2. [CrossRef]

44. İşçioğlu D. Bebek Beslenmesi İçin Seçtiğimiz Ürünlerin Bpa İçermemesi Yetmez. 2015. Retrieved from http://www.otcnews.com.tr/bebekbeslenmesi-icin-sectigimizurunlerin-bpaicermemesi-yetmez/

45. Commission Decision (EU) 2017/1392 of 25 July 2017 amending Decision 2014/350/EU establishing the ecological criteria for the award of the EU Ecolabel for textile products.

46. Commission Regulation (EU) 2016/2235 of 12 December 2016 amending Annex XVII to Regulation (EC) No 1907/2006 of the European Parliament and of the Council concerning the Registration, Evaluation, Authorisation and Restriction of Chemicals (REA$\mathrm{CH}$ ) as regards bisphenol $\mathrm{A}$. [CrossRef]

47. Xue J, Liu W, Kannan K. Bisphenols, benzophenones, and bisphenol A diglycidylv ethers in textiles and infant clothing. Environ Sci Technol 2017; 51(9): 5279-86. [CrossRef]

48. Li AJ, Kannan K. Elevated concentrations of bisphenols, benzophenones, and antimicrobials in pantyhose collected from six countries. Environ Sci Technol 2018; 52: 10812-9. [CrossRef]
49. Freire C, Molina-Molina JM, Iribarne-Durán LM, Jiménez-Díaz I, Vela-Soria F, Mustieles V, et al. Concentrations of bisphenol A and parabens in socks for infants and young children in Spain and their hormone-like activities. Environ Int 2019; 127: 592-600. [CrossRef]

50. Street ME, Bernasconi S. Endocrine-Disrupting Chemicals in $\mathrm{Hu}-$ man Fetal Growth. Int J Mol Sci 2020; 21(4): 1430. [CrossRef]

51. Zhang XL, Wang HS, Liu N, Ge LC. Bisphenol A stimulates the epithelial mesenchymal transition of estrogen negative breast cancer cells via FOXA1 signals. Arch Biochem Biophys 2015; 585: 10-6. [CrossRef]

52. Arukwe A. Cellular and molecular responses to endocrine-modulators and the impact on fish reproduction. Marine Pollution Bulletin 2001; 42(8): 643-55. [CrossRef]

53. Ecotextiles. Bisphenol A in textile processing? https:// oecotextiles. wordpress.com/ 2011/12/16/ bisphenol-a-in-textile. processing/ (accessed Jan 20, 2017).

54. Bisphneol A. Directive 2014/81/EU amending Appendix C of Annex Il to directive 2009 /48/ EC. http: // www.btha.co.uk/ wp- content/ uploads/ 2015/06/ BPA-Guide-Version-1.pdf (accessed Jan 20, 2017).

55. Herva M, Alvarez A, Roca E. 2011. Sustainable and Safe Design of Footwear Integrating Ecological Footprint and Risk Criteria, Journal of Hazardous Materials, 2011;192. [CrossRef]

56. Greenpeace. Dirty laundry: Unravelling the corporate connections to toxic water pollution in China; Greenpeace International: Amsterdam, The Netherlands, 2014.

57. Hsieh TH, Tsai CF, Hsu CY, Kuo PL, Lee JN, Chai CY, et al. Phthalates stimulate the epithelial to mesenchymal transition through an HDAC6-dependent mechanism in human breast epithelial stem cells. Toxicol Sci 2012; 128: 365-76. [CrossRef]

58. Teilmann G, Juul A, Skakkebık NE, Toppari J. Putative effects of endocrine disrupters on pubertal development in the human. Best Practice \& Research Clinical Endocrinology \& Metabolism 2020; 16(1): 105-21. [CrossRef]

59. Geyer JH, Rimkus GG, Scheunert I, Kaune A, Schramm KW, Kettrup $A$, et al. Bioaccumulation abd occurrence of endocrine disrupting chemicals (EDCs), persistent organic pollutants (POPs), and other organic compounds in fish and other organisms including humans. The Handbook of Environmental Chemistry 2000; 2: 1-166. [CrossRef]

60. Lacasse K, Baumann W. Textile Chemicals: Environmental Data and Facts. Springer Berlin Heidelberg: New York, 2004.p.609. [CrossRef]

61. Ecotextiles. Choosing a fabric for your new sofa. https:// oecotextiles.wordpress.com /tag/ bisphenol-a/ (accessed Jan 20, 2017).

62. Xue J, Liu W, Kannan K. Bisphenols, Benzophenones, and Bisphenol A Diglycidyl Ethers in Textiles and Infant Clothing. Environ Sci Technol 2017; 51(9): 5279-5286. [CrossRef]

63. AndricNL, KosticTS, ZoricSN, StanicBD, AndricSA, KovacevicRZ. Effect of a PCB based transformer oil on testicular steroidogenesis and xenobiotic-metabolizing enzymes. Reprod Toxicol 2006; 22: 102-10. [CrossRef]

64. Herva M, Alvarez A, Roca E. Sustainable and Safe Design of Footwear Integrating Ecological Footprint and Risk Criteria, Journal of Hazardous Materials 2011.p.192. [CrossRef]

65. Eurofins, Analytical reports; Testing of textile with prints (Disney products), December 2003.

66. Nakajima T, Hopf NB, Schulte PA, Di(2-ethylhexyl) phthalate (DEHP) 2000. Internet Adresi: https://monographs.iarc.fr/ENG/ Publications/ techrep42/TR42-18.pdf, (accessed 08.03.2017)

67. Cetinkaya S. Endokrin Bozucular ve Ergenlik Üzerine Etkileri. Dicle Tıp Dergisi 2009; 36(1): 59-66. 
68. Erkekoglu P, Kocer-Gumusel B. Environmental Effects of Endocrine-Disrupting Chemicals: A Special Focus on Phthalates and Bisphenol A, Environmental Health Risk -Hazardous Factors to Living Species, Marcelo L. Larramendy and Sonia Soloneski, 2016 IntechOpen. [CrossRef]

69. European Commission. $(2008,2015)$. Opinion on the safety of medical devices containing DEHP - plasticized PVC or other plasticizers on neonates and other groups possibly at risk. (Available from: https://ec.europa.eu/health/scientifc_committees/emerging/docs/scenihr_o_047.pdf)(accessed 09.03.2017)

70. Combarnous Y, Nguyen TMD. Comparative Overview of the Mechanisms of Action of Hormones and Endocrine Disruptor Compounds. Toxics 2019; 7(1): 5. [CrossRef]

71. Heudorf U, Mersch-Sundermann V, Angerer J. Phthalates: Toxicology and exposure. Int J Hyg Environ Health 2007; 210: 623-34. [CrossRef]

72. Bizzari S, Oppenberg B, Iskikawa Y. Plasticizers, Chemical Economics Handbook, Palo Alto, CA: SRI International, 2000.

73. Giuliani A, Zuccarini M, Cichelli A, Khan H, Reale M. Critical Review on the Presence of Phthalates in Food and Evidence of Their Biological Impact. Int J Environ Res Public Health 2020; 17(16): 5655. [CrossRef]

74. NRC, Phthalates Cumulative Risk Assessment - The Tasks Ahead. Committee on Phthalates Health Risks, National Research Council, National Academy of Sciences, Board on Environmental Science and Technology, National Academy Press, Washington, DC, 2008.

75. Swan S, Sathyanarayana S, Barrett E, Janssen S, Liu F, Nguyen R, et al. First trimester phthalate exposure and anogenital distance in newborns. Human Reproduction 2015; 30(4): 963-72. [CrossRef]

76. Pich CD, Sauvageau D, VanlianM, Erythrope IHC, Robaire B, Leask RL. Effects of di- (2-ethylhexyl) phthalate and four of its metabolites on steroidogenesis in MA-10 cells. Ecotoxicol Environ Safety 2012; 79: 108-15. [CrossRef]

77. Chen X, Zhou QH, Leng L, Chen X, Sun ZR, Tang NJ. Effects of di(nbutyl) and monobutyl phthalate on steroidogenesis pathways in the murine Leydig tumor cell line MLTC-1. Environ Toxicol Pharmacol 2013; 36: 332-8. [CrossRef]

78. Jeddi MZ, Janani L, Memari AH, Akhondzadeh S, Yunesian M. The role of phthalate esters in autism development: A systematic review. Environmental Research 2016; 151: 493-504. [CrossRef]

79. Marina T. Guerra Hayley C. Furlong Wilma G. Kempinas Warren G. Foster. Effects of in vitro exposure to butylparaben and di-(2 ethyIhexyl) phthalate, alone or in combination, on ovarian function. Applied Toxicology 2016; 36:1235-45. [CrossRef]

80. Cimini AM, Sulli A, Stefanini S, Serafini B, Moreno S, Rossi L, et al. Effects of Di-(2-ethylhexyl)phthalate on peroxisomes of liver, kidney and brain of lactating rats and their pups. Cellular and Molecular Biology (Noisy-le-Grand, France) 1994; 40(8): 1063-76.

81. Duty SM, Calafat AM, Silva MJ, Ryan L, Hauser R. Phthalate exposure and reproductive hormones in adult men. Hum Reprod 2005; 20(3): 604-10. [CrossRef]
82. Nakajima, Hopf NB, Schulte PA. Di(2-ethylhexyl) phthalate (DEHP) 2000 (Available from: https://monographs.iarc.fr/ENG/Publications/ techrep42/TR42-18.pdf) (Accessed 08.03.2017)

83. Guo Y, Wu Q, Kannan K. Phthalate metabolites in urine from China, and implications for human exposures. Environment International 2011; 37(5): 893-8. [CrossRef]

84. Hines CJ, Hopf NB, Deddens JA, Silva MJ, Calafat AM. Estimated daily intake of phthalates in occupationally exposed groups. Journal of Exposure Science and Environmental Epidemiology 2011; 21(2): 133-41. [CrossRef]

85. European Commission. $(2008,2015)$. Opinion on the safety of medical devices containing DEHP - plasticized PVC or other plasticizers on neonates and other groups possibly at risk. (Available from:https://ec.europa.eu/health/scientifc_committees/emerging/docs/scenihr_o_047.pdf.(Accessed 09.03.2017)

86. Green R, Hauser R, Calafat AM, Weuve J, Schettler T, Ringer S, et al. Use of di (2-ethylhexyl) phthalate-containing medical products and urinary levels of mono (2-ethylhexyl) phthalate in neonatal intensive care unit infants. Environmental Health Perspectives 2005; 1222-5. [CrossRef]

87. FDA (Food and Drug Administration) (2003). Safety Assessment of Di(2-ethylhexyl)phthalate (DEHP) Released from PVC Medical Devices. (Available from:: https://www.fda.gov/downloads/ MedicalDevices/.../UCM080457.pdf.) .(Accessed 02.03.2017)

88. Carlstedt F, Jönsson B, Bornehag CG. PVC flooring is related to human uptake of phthalates in infants. Indoor Air 2013; 23(1): 329. [CrossRef]

89. Rudel RA, Perovich LJ. Endocrine disrupting chemicals in indoor and outdoor air. Atmospheric Environment 2009; 43(1): 170-81. [CrossRef]

90. Wittassek M, Angerer J. Phthalates: metabolism and exposure. International Journal of Andrology 2008; 31(2):131-8. [CrossRef]

91. Olsén $L$, Lind L, Lind PM. Associations between circulating levels of bisphenol $\mathrm{A}$ and phthalate metabolites and coronary risk in the elderly. Ecotoxicol Environ Saf 2012; 80: 179-83. [CrossRef]

92. Frederiksen $\mathrm{H}$, Skakkebaek NE, Andersson AM. Metabolism of phthalates in humans. Mol Nutr Food Res 2007; 51(7): 899-911. [CrossRef]

93. Kim SH, Park MJ. Phthalate exposure and childhood obesity. Ann Pediatr Endocrinol Metab 2014; 19(2): 69-75. [CrossRef]

94. Ait Bamai Y, Araki A, Kawai T, Tsuboi T, Yoshioka E, Kanazawa A, et al. Comparisons of urinary phthalate metabolites and daily phthalate intakes among Japanese families. Int J Hyg Environ Health 2015; 218(5): 461-70. [CrossRef]

95. Pedersen H, Hartmann J. Greenpeace Investigations Corporate Crimes "The Walt Disney Company is always concerned with quality and safety" Letter To Greenpeace. Brussels, 2004; ISBN number: 90-73361-83-4, 2003. 